Chapman University

Chapman University Digital Commons

English Faculty Articles and Research

English

Spring 2020

\title{
Twinship and Marriage in The Comedy of Errors
}

Kent R. Lehnhof

Follow this and additional works at: https://digitalcommons.chapman.edu/english_articles

Part of the Dramatic Literature, Criticism and Theory Commons, Literature in English, British Isles Commons, and the Theatre History Commons 


\section{Twinship and Marriage in The Comedy of Errors}

\section{Comments}

This is a pre-copy-editing, author-produced PDF of an article accepted for publication in SEL Studies in English Literature 1500-1900, volume 60, issue 2, in 2020 following peer review. The definitive publisherauthenticated version is available online at https://doi.org/10.1353/sel.2020.0012

\section{Copyright}

(c)Rice University. Published by Johns Hopkins University Press. 


\section{Twinship and Marriage in The Comedy of Errors}

KENT R. LEHNHOF

In the second scene of The Comedy of Errors, Antipholus of Syracuse alights in Ephesus, intent on finding the sibling from whom he was separated as an infant. Apart from his identical twin, Antipholus S feels anonymously out-of-sorts. He is, he tells us, like a drop of water swallowed up by a great, undifferentiating ocean.

I to the world am like a drop of water

That in the ocean seeks another drop, Who, falling there to find his fellow forth, Unseen, inquisitive, confounds himself.

So I, to find a mother and a brother, In quest of them, unhappy, lose myself. $\left(\right.$ I.ii.35-40) ${ }^{1}$

This metaphor of self-dissolution is striking in itself, but what makes it even more striking is its reappearance in the very next act. Within 300 lines, Adriana is using the same conceit of watery combination to describe her marital union with her husband:

Ah, do not tear away thyself from me;

For know, my love, as easy mayst thou fall

A drop of water in the breaking gulf,

And take unmingled thence that drop again

\footnotetext{
${ }^{1}$ All references to Shakespeare, cited parenthetically throughout, come from The Norton Shakespeare, ed. Stephen Greenblatt et al. (New York: W. W. Norton, 1997).
} 
Without addition or diminishing,

As take from me thyself, and not me too. (II.ii.124-9) ${ }^{2}$

By repeating the metaphor, Shakespeare invites us to connect these two conversations, comparing the claims of each character. Both Adriana and Antipholus S use the trope to talk about family relationships, but one focuses on the marital relation and the other on the twin relation. The distinction appears to be significant, inasmuch as Adriana and Antipholus S leverage their shared metaphor in very different directions. Whereas Adriana says that her conjugal union with Antipholus $\mathrm{E}$ has dissolved their individual selves, Antipholus S suggests that uniting with his twin will have the opposite effect, arresting and even reversing the selfdissolution he experiences on his own. These connected yet competing metaphors--coming quite early in the action--set the table for a sustained investigation of interpersonal relation, especially as concerns twinship and marriage. Throughout the comedy, Shakespeare provocatively juxtaposes twinship and marriage, prompting us to reflect on the affective impact and identity effects of these two forms of intimate association. ${ }^{3}$

\footnotetext{
${ }^{2}$ David Schalkwyk notes that the comedy and poignancy of this speech is compounded by the fact that Adriana addresses it to the wrong Antipholus. See David Schalkwyk, Shakespeare, Love and Service (Cambridge: Cambridge Univ. Press, 2008), p. 89.

${ }^{3} \mathrm{~A}$ number of scholars have written insightfully about interrelationship and identity in The Comedy of Errors. In using twinship and marriage to think through these matters, I work in parallel with those who have discussed selfhood in the play using other points of entry, including time and sequence (Salgado), materiality (Lanier), memory and money (Raman), sympathy and possession (Cartwright), love and service (Schalkwyk), and interaction ritual and social ceremony (Findlay). My analysis also runs alongside the interpretation of Thomas Luxon, who similarly sees the play as staging a contest between twinship and marriage, although his characterization of this contest is quite different from my own. See Gamini Salgado, "'Time's Deformed Hand': Sequence, Consequence, and Inconsequence in The Comedy of Errors," ShS 25, ed. Kenneth Muir (Cambridge: Cambridge Univ. Press, 1972), pp. 81-91; Douglas Lanier, "'Stigmatical in Making': The Material Character of The Comedy of Errors," ELR 23, 1 (Winter 1993): 81-112; Shankar Raman, "Marking Time: Memory and Market in The Comedy of Errors," SQ 56, 2 (Summer 2005): 176-205; Kent Cartwright, "Language, Magic, the Dromios, and The Comedy of Errors," SEL 47, 2 (Spring 2007): 331-54; Schalkwyk, esp. pp. 80-97; Alison Findlay, "Ceremony and Selfhood in
} 
On the face of it, twinship and marriage might seem quite different kinds of connection. Whereas twinship is a material relation, predicated upon shared blood and simultaneous birth, marriage is a social relation, dependent upon ceremony and law. In marriage, individuals elect to share their lives with one another, but in twinship the life-sharing begins in utero, before either twin is self-aware or capable of choice. ${ }^{4}$ Statistically speaking, marriage is a common occurrence, while multiple births are relatively rare, which puts the former in the realm of the ordinary or familiar and the latter in the realm of the extraordinary or unusual. Nevertheless, both marriage and twinship are envisioned in the early modern period and in Shakespeare's plays as total unions, to the point of blurring the line between the self and the other. In Shakespeare's day, the prevailing conceptualization of marriage comes from the book of Genesis, which says that husbands and wives become "one flesh," their separate beings combining to form a single essence (Gen. 2:24). Twinship was similarly envisioned as a blending of the one and the two. As Shakespeare's Orsino advises, twins possess "one face, one voice, one habit, and two persons" (Twelfth Night V.i.208). Two persons, but one flesh; one face, but two persons: both twinship and marriage are mathematically complex, running counter to conventional modes of counting and accounting. To the extent that they straddle the same

The Comedy of Errors," in The Oxford Handbook of Tudor Drama, ed. Thomas Betteridge and Greg Walker (Oxford: Oxford Univ. Press, 2012), pp. 338-54; and Thomas H. Luxon, "Humanist Marriage and The Comedy of Errors," Ren\&R, n.s. 25, 4 (Fall 2001): 45-65.

${ }^{4}$ Although marital consent may have been more notional than real for certain members of society-such as elite individuals entering into arranged marriages--the giving of consent was nevertheless an indispensable part of the early modern marriage ceremony. The Book of Common Prayer required both parties to declare their willingness to unite by giving an affirmative answer to the questions "Wilt thou have thys woman to be thy wedded wyfe ... ?" and "Wilt thou have this man to be thy wedded housband ... ?" See The Book of Common Prayer, www.justus.anglican.org/resources/bcp/1559/BCP_1559.htm. 
boundary between the monad and the dyad, twinship and marriage stand proximate to one another as deep relational paradoxes.

Relational paradoxes of this kind fired the early modern imagination, causing a great many authors to explore the idea of oneself-as-another in the contexts of marriage and friendship. Shakespeare, however, takes this collective interest in a novel direction by turning his attention to twins. His focus on twins, and the specific choices he makes in depicting their relationship, distinguish him from his peers. Indeed, Daisy Murray argues that in his handling of the twinship situation, "Shakespeare proves not only unique, but revolutionary." ${ }^{5}$ Murray makes this claim in her book-length study of twin plays in early modern England. In this work, Murray contends that most twin plays from the period portray the relationship prejudicially, perpetuating the belief that twinship is a cursed or monstrous condition originating in and characterized by intemperance, unnaturalness, immorality, and excess. She shows that Shakespeare, by contrast, makes a concerted effort to dispel these detrimental ideas, ultimately articulating a remarkably positive and progressive portrayal of twinship. In this regard, Murray's work corroborates John Lee's earlier assertion that twinship is one of the things that makes Shakespeare's art distinctively Shakespearean. ${ }^{6}$ In her concluding chapter, Murray speculates that Shakespeare's atypical and enlightened approach toward twins might be linked to his own lived experience, inasmuch as he was himself father to a set of opposite-

${ }^{5}$ Daisy Murray, Twins in Early Modern English Drama and Shakespeare (New York and London: Routledge, 2017), p. 175.

${ }^{6}$ See John Lee, "Twins and Doubles as an Aspect of Shakespeare's Pluralism," in The Shakespearean International Yearbook 4, ed. Graham Bradshaw, Tom Bishop, and Mark Turner (Aldershot: Ashgate, 2004), pp. 316-36, esp. 318. 
sex twins, Judith and Hamnet. ${ }^{7}$ Without gainsaying this position, I propose that the sophisticated way in which Shakespeare plays with his twin characters--even in the context of a frolicking farce like The Comedy of Errors--indicates that his interest in twins has philosophical dimensions as well as biographical ones. To my view, Shakespeare's twin plays are best seen as a manifestation of his abiding interest in the way interpersonal relationships can be both selfconsuming and self-constituting. ${ }^{8}$ When one is intent on exploring the experience and effects of interrelation, as I believe Shakespeare was, then twins are of especial interest, for they are always already in relation. Indeed, twins can never not be in relation, for even when one twin is absent, either through distance or death, he or she continues to be present: embodied and expressed in the person of his or her sibling.

This heightened state of interrelation, I believe, underlies Shakespeare's decision to write twin plays. His desire to probe what it means to be tied to others induces him to add twinship pairs to the standard playhouse fare of friends and lovers. By including twinned characters, Shakespeare increases the possibilities for silly comedic mistakes but also prepares the way for far-reaching investigations into the nature of interconnection and identity. In what follows, I wish to consider how Shakespeare actualizes these myriad potentialities in The Comedy of Errors. As I will show, Shakespeare's strategy in this particular play is to multiply twinship ties and marital bonds until all of his principal characters are enmeshed in a dense web of interpersonal relationships, each of which is imagined to be all-encompassing. In this setting,

\footnotetext{
${ }^{7}$ Murray, p. 181.

${ }^{8}$ For a keen analysis of Shakespeare's interest in interpersonal relations, see Nancy Selleck, The Interpersonal Idiom in Shakespeare, Donne, and Early Modern Culture (Basingstoke and New York: Palgrave Macmillan, 2008).
} 
where the attachments between spouses and twins make it difficult to disentangle discrete subjectivities or demarcate individual boundaries, Shakespeare explores the nature and essence of identity. In this play, Shakespeare invites us to consider how our sense of self can be constituted, confirmed, and compromised by and through a whole host of interrelationships, ranging from the more familiar bonds of matrimony to the more fantastical bonds of twinship.

\section{Twinship}

In her study of contemporary texts, Juliana de Nooy has demonstrated that modern-day authors often use twins to explore and unsettle basic ideas about identity and individuality. Shakespeare anticipates this practice in both of his twin plays. When Viola and Sebastian, for example, are finally reunited at the end of Twelfth Night, their self-sameness excites both wonder and consternation. Orsino is not alone in not knowing what to make of this "natural perspective, that is and is not" (V.i.209). As Orsino's words indicate, twinship pairs pose an ontological problem. Caught between the one and the two, they frustrate our efforts to distinguish and separate, to tally and add. But even more than this, they expose the fundamental ambiguity of "identity" itself, a term that paradoxically connotes both oneness (identity as in-dividuality) and twoness (identity as identical-ness). ${ }^{9}$ If, as de Nooy declares, twins in modern times are utilized to interrogate "the undecidability between the twoness and the oneness of identity--between the identical and the individual, the split and the whole," then

\footnotetext{
${ }^{9}$ Juliana de Nooy illustrates this ambiguity by noting that identité is defined in the authoritative French dictionary Le Petit Robert as both "the quality of two identical objects of thought" (caractère de deux objets de pensée identiques) and as "the quality of oneness" (caractère de ce qui est un). Juliana de Nooy, Twins in Contemporary Literature and Culture (Basingstoke and New York: Palgrave Macmillan, 2005), p. 179 n. 11.
} 
the final scene of Twelfth Night might give us one more reason to consider Shakespeare our contemporary. ${ }^{10}$

However, it is at least somewhat misleading to privilege this particular moment in the play, since the opposite-sex siblings are relatively easy to distinguish elsewhere. Viola may resemble her brother in outward appearance, but her actions are not of the same order as his. Whereas she trembles, cowers, and quakes in the face of violence, he vigorously breaks pates and bloodies coxcombs. The obvious disparity in their conduct attests to an essential division between the male and the female. As C. L. Barber puts it, "The most fundamental distinction the play brings home to us is the difference between men and women." 11 In this regard, the twins of Twelfth Night tend to clarify, rather than confuse, conventional categories of selfhood. Their close relation becomes the means of asserting and amplifying a dichotomous sexual essentialism. For all of their apparent similarity, Viola's and Sebastian's sexed bodies set them apart, affixing each twin in a gendered space that circumscribes the self within certain parameters. Anatomy, it would seem, is destiny--even among twins. ${ }^{12}$

\footnotetext{
${ }^{10}$ de Nooy, p. 121.
}

${ }^{11}$ C. L. Barber, Shakespeare's Festive Comedy (Princeton: Princeton Univ. Press, 1959), p. 245.

${ }^{12}$ Although Twelfth Night endorses a binaristic understanding of anatomy, its treatment of sexual attraction is quite different. The ease with which erotic desire shifts and flows from one twin to the other over the course of the play precludes any pat homo/hetero distinctions. As Lisa Jardine observes, desire in Twelfth Night is focused upon boys and women in the same way, and the erotic interchangeability of the opposite-sex twins indicates that availability is much more important than anatomy in romantic affairs. In this respect, Shakespeare's staging of the twin relation in Twelfth Night points to an erotic fluidity that suffuses the Renaissance stage in particular and early modern culture in general. See Lisa Jardine, "Twins and Travesties: Gender, Dependency, and Sexual Availability in Twelfth Night," in Erotic Politics: Desire on the Renaissance Stage, ed. Susan Zimmerman (New York and London: Routledge, 1992), pp. 27-38, esp. 28. 
But the situation is otherwise in The Comedy of Errors. Although Viola and Sebastian only appear similar in Twelfth Night, the twins in Errors actually are identical, right down to the smallest detail. As Egeon tells the Duke, each of his sons was "so like the other / As could not be distinguished but by names" (I.i.51-2). Before long, even this soft form of separation disappears, as each of the Syracusan brothers decides to memorialize his missing twin by taking his name. This nominal overlap is confusing enough, yet the comedy goes even further, indicating that its twins not only answer to the same name but also have the same "privy marks" about them. We learn this to be true of the Dromios when Nell, the kitchen wench, encounters Dromio S (the wrong twin) and lays claim to him by listing off all of the distinguishing features she has noted on the body of his brother:

[T]his drudge or diviner laid claim to me, called me Dromio, swore I was assured to her, told me what privy marks I had about me--as the mark of my shoulder, the mole in my neck, the great wart on my left arm--that I, amazed, ran from her as a witch. (III.ii.138-42) That Dromio S feels himself attainted in the physical inventory of his sibling suggests that there is complete corporeal correspondence between the two. As incredible as it may be, the selfsameness of the Dromio twins is so absolute that they share the same marks, moles, and warts. By pushing the twin relation to the point of exact similitude, The Comedy of Errors enters the realm of implausibility, of farce. Yet it does so in a way that invites us to reflect on the underpinnings of identity. In particular, it prompts us to consider how selfhood can be produced and preserved in the absence of anything personally distinctive or unique. When 
there is no objective way to tell two people apart, what can be the basis for the self? Is identity even possible, if one is not singular?

Questions such as these are begged by questions the characters ask onstage. Dromio S, for instance, responds to his confrontation with Nell in the kitchen by accosting his master and asking, "Do you know me, sir? Am I Dromio? Am I your man? Am I myself?" (III.ii.73-4).

Similarly, a confusing exchange with Adriana causes Antipholus S to wonder, "Am I in earth, in heaven, or in hell? / Sleep or waking? Mad or well advised? / Known unto these, and to myself disguised!" (II.ii.212-4). In this city where neither twin is physically or nominally unique, each experiences a crisis of identity. As Alison Findlay has argued, these crises do much to dramatize the self-endowing importance of everyday social interactions--those small ceremonial exchanges (like greetings and partings) that Erving Goffman calls "face-work." When the twins' physical similarities cause them to be mistaken for each other, they find themselves unable to follow or execute the expected social script, and the loss of "face" they thereby undergo is experienced by them as a loss of self. ${ }^{13}$ Martine van Elk has shown that this scenario would have resonated with Shakespeare's audience members, who were both fascinated and frightened by stories of cunning coney-catchers and their devious schemes to steal the identities of unsuspecting marks. According to van Elk, Shakespeare's play, like the coneycatching pamphlets with which it is allied, sends the message that social identity is not fixed and inalienable but is open to exchange, usurpation, theft, and loss. ${ }^{14}$ These readings are rich

\footnotetext{
${ }^{13}$ See Findlay.

${ }^{14}$ See Martine van Elk, "Urban Misidentification in The Comedy of Errors and the Cony-Catching Pamphlets," SEL 43, 2 (Spring 2003): 323-46.
} 
and insightful; however, their repeated references to identity "loss" perhaps promote the misperception that each twin's identity is stripped away as the events unfold, leaving him with no identity at all. This does not seem accurate to me. As I see it, the central predicament of the play has less to do with the loss of identity than with its opposite: the superabundance of identity. What each twin finds troubling is not that nobody knows him but that everybody knows him--and uses this knowledge to make claims on him. The twins are not perplexed because they have no identity but because they have too much identity--to the point that they are constantly being summoned, called, and commanded by strangers. This is a different kind of crisis than the instances of identity theft we find in the coney-catching pamphlets. In The Comedy of Errors, Shakespeare uses his twins to stage a curious kind of confusion. To be a twin in this play is not to be anonymous or unknown but rather to be overwhelmed by obligations one does not understand--to buckle beneath the weight of responsibilities and commitments one did not knowingly incur or willingly assume.

The effect of all this surplus responsibility is to make the twins doubt their sanity and question themselves. And they will continue to do so as long as they are out of sorts with their obligations. Self-identity in this play does not begin to solidify until the brothers finally come face-to-face and start to sort through their respective responsibilities, relinquishing those that belong to the other and acknowledging those that are their own. In this way, the play implies a close association between selfhood, on the one hand, and responsibility and relation, on the other. Indeed, obligation and interrelation appear to operate as the principal sources of selfhood in this play. For if the twins in Errors eventually achieve a state of self-distinction, it is not because they start to exhibit a distinctive set of personal characteristics but because they 
begin to honor a distinctive set of personal obligations--to this or that woman, to this or that master, to this or that merchant. Each twin acquires his own identity as he is differently situated within a network of relations and charged with a unique set of responsibilities he endeavors to uphold.

This emphasis on the relational nature of identity would seem to be characteristic of Shakespeare's day. Whereas later authors increasingly attend to the idea of the inward self, sixteenth century writers tend to privilege the external over the internal, the public over the private. It is therefore to be expected that a drama dating from the 1590s--when twentieth century ideas about individuality and interiority are not yet established--would present selfhood in strongly social terms. ${ }^{15}$ Yet I believe that Shakespeare's handling of the theme goes beyond this, to the point of suggesting that selfhood can only emerge in relation to the other and is necessarily delineated by the obligations that attend this relation. ${ }^{16}$ According to this line of thinking, there must be a "you" before there can be an "I," and what makes each "I" distinctive is a distinctive set of interpersonal duties.

The foundation for this idea is laid as early as I.ii, when Antipholus S speaks of himself as being all alone in the world. At this point in the action--before the comedy of errors has properly begun--Antipholus does talk about his selfhood as having been lost or stripped away.

${ }^{15}$ Landmark studies in early modern ideas of inwardness and interiority include Francis Barker, The Tremulous Private Body: Essays on Subjection (New York: Methuen, 1984); Ann Rosalind Jones and Peter Stallybrass, "The Politics of Astrophil and Stella," SEL 24, 1 (Winter 1984): 53-68; Catherine Belsey, The Subject of Tragedy: Identity and Difference in Renaissance Drama (New York: Methuen, 1985); Kay Stockholder, "'Yet Can He Write': Reading the Silences in The Spanish Tragedy," Al 47, 2 (Summer 1990): 93-124; and Katharine Eisaman Maus, Inwardness and Theater in the English Renaissance (Chicago: Univ. of Chicago Press, 1995).

${ }^{16}$ Schalkwyk makes a similar claim, advising that the play points to "the difficulty, if not the impossibility, of achieving one's 'own content' without the ties that bind the self to others" (pp. 88-9). 
Dissevered from his family members, Antipholus $\mathrm{S}$ feels anonymous and indistinct: the drop of water dissolved within a vast sea (see I.ii.33-40). At the very start of the play, Antipholus S indicates that a self outside of all relation is no self at all. Unless it is tied to other people, the "I" cannot exist as such; it can be nothing more than an unseen confusion. ${ }^{17}$ As Antipholus $\mathrm{S}$ sees it, the way to acquire (or re-acquire) selfhood, is to re-connect with the brother and mother for whom he has been searching, forging anew the familial bonds that inform the ego.

Of these family ties, the ones that bind him to his brother appear particularly important. As Kent Cartwright has shown, the play suggests in a number of places that its twins share a secret sympathy with each other, such that the experiences and emotions of one twin appear to transfer unaccountably to the other. ${ }^{18}$ The idea that twins might share a metaphysical bond has long been a part of our cultural heritage and continues to inform our popular culture. Even today, we speak of "twin telepathy" and gravitate toward stories of twins who somehow sense when their counterpart is in pain or danger. ${ }^{19}$ When two persons are paired in the womb, it is easy to imagine that they would remain connected, even at a distance. Telepathy aside, however, there is a way in which identical twins remain in relation even when apart, inasmuch

${ }^{17}$ Before long, however, the Ephesians begin greeting Antipholus by name and he swings from one pole to the other, from having no identity to having too much identity, as discussed above.

${ }^{18}$ According to Cartwright, the play often indicates that, "The fears of the first brother are materialized, made manifest, in the sufferings of the second, as if the twins shared a kind of psychic reciprocity, a sympathy, whereby the thoughts of one might fashion or conjure forth the experiences of the other" (p. 342). Cartwright, however, does not limit this psychic link to the twins. In his view, the telepathy exhibited by the brothers extends throughout Ephesus, to the point that metaphysical communication or contagion becomes the signal feature of the play's sociality.

${ }^{19}$ This trope of twinship is quintessentially articulated in Alexandre Dumas's novel The Corsican Brothers. The allure of this conceit is evidenced by the fact that Dumas's novel has been adapted into film no fewer than 18 times--which number includes the 1984 parody by comedians Cheech and Chong but does not include the recurring "Corsican Twins" sketch on the children's television show The Electric Company. 
as each twin embodies and thereby re-presents his missing sibling. This is especially true in Errors, where each twin not only bears his brother's image but also bears his brother's name. ${ }^{20}$ To be sure, twins embody interrelatedness at every level--along with all that this might mean with regard to selfhood. At the same time, however, twins lack the personal distinctiveness that would seem to be a prerequisite for self-identity. This makes it so that twins occupy the axes of identity differently than most, which seems to account for Shakespeare's interest. By playing with twins, Shakespeare is able to take us to the extreme verge, using their exceptional situation to extend our thinking about identity and interrelation.

When The Comedy of Errors, begins, Shakespeare's twins are out of touch with each other, which makes Antipholus S feel out of touch with himself. Alienated from his brother--as well as his father and mother--Antipholus $\mathrm{S}$ undergoes a dissolution of self that conveys the idea that personal identity is a function of familial ties. It is certainly true that Antipholus $E$, tightly enmeshed in a host of domestic alliances, does not evince any of his brother's subjective distress--until such time, that is, that his household relations are upset by the arrival of his twin. At this point, the crisis engrosses both twins, along with a number of other characters. As the crisis expands in scope, it also alters in quality so that the primary problem shifts from having too little identity to having too much identity. Antipholus S may feel indistinct and anonymous at the outset, but he is soon called forth and called upon by a bewildering number of complete strangers. The obligations these strangers heap upon him are excessive. He cannot grasp their origin or their extent, and he despairs of ever being on equal footing with those around him.

${ }^{20} \mathrm{cf}$. Findlay's claim that the siblings in Errors "function as revenants: each twin's name and form keeps alive the memory of his other/brother" (p. 350). 
For philosophers of a certain stripe, this sense of overwhelming responsibility is the ethical response par excellence to the world in which we find ourselves. Emmanuel Levinas, for instance, insists that the ego is accountable to everyone it encounters, whether it accepts this responsibility or not. ${ }^{21}$ To illustrate and advocate for this ultra-rigorous understanding, Levinas often quotes a passage from The Brothers Karamazov, where one of the characters comes to realize: "We are all guilty of all and for all men before all, and I more than the others."22 If Levinas and Dostoevsky, however, present this state of absolute obligation as a universal truth, Shakespeare depicts it largely as a comedy of errors: a consequence of misrecognitions and mistakes. By rights, the excessive obligations that overburden each twin belong to another: the twin who pledged his love, the brother who received the chain, the servant who accepted the task. In The Comedy of Errors, then, the resolution of the dilemma depends less on the assumption of responsibility than on the reordering or restructuring of it. The task the twins face is not to surrender entirely to the other (pace Levinas) but simply to sort out their obligations, once more circumscribing them within the conventional duties shouldered by masters and servants, clients and craftsmen, husbands and wives.

By repositioning each twin within these familiar social forms and arrangements, the play extracts them from the state of perpetual obligation in which their self-sameness has temporarily immersed them. At play's end, teach twin's obligations appear more manageable because each twin is now responsible only for his own actions and acquaintances.

\footnotetext{
${ }^{21}$ See Emmanuel Levinas, Ethics and Infinity, trans. Richard A. Cohen (Pittsburgh: Duquesne Univ. Press, 1985), esp. pp. 95-101.

${ }^{22}$ Fyodor Dostoyevsky, The Brothers Karamazov, trans. Constance Garnett (New York: New American Library, 1957), p. 264.
} 
Nevertheless, the drama perhaps troubles this easy ending by intimating throughout that one of these "conventional" relations--the conjugal one--might be all-consuming in its own right.

II. Marriage

Although early modern comedies generally drive toward and thereby endorse the institution of marriage, conjugal relations loom especially large in Errors, where almost all of the principal characters are either married (Emilia/Egeon, Adriana/Antipholus E) or about to be married (Nell/Dromio E, Luciana/Antipholus S). The play presents us with romantic alliances among the merchant class, as well as among the servant class. We are given to see couples just setting out on their journey together, spouses trying to navigate marital waters that have turned turbulent, and life partners attempting to resume a relationship that was brought to wrack decades earlier. This panoply of relationships prompts us to consider marriage's myriad forms and phases, as well as the many ways it shapes, molds, and impacts its participants. Indeed, Barbara Freedman has compellingly claimed that everything in the play--from its parallel plots to its recurrent jokes to its financial complications to its deep symbolic structure-reflects an abiding concern for unpaid marital debts. In her view, marriage and the obligations it imposes is the principal theme of the play: the hub around which the whole farce revolves. ${ }^{23}$

Shakespeare's desire to focus our attention on marriage most likely motivates his decision to relocate the action of the play from Epidamnus, where Plautus set it, to Ephesus, where everything would be colored by Paul's counsel to married couples, as set forth in his

\footnotetext{
${ }^{23}$ See Barbara Freedman, "Errors in Comedy: A Psychoanalytic Theory of Farce," in Shakespearean Comedy, ed. Maurice Charney (New York: New York Literary Forum, 1980), pp. 233-43.
} 
epistle to the Ephesians. ${ }^{24}$ It is in this epistle that Paul famously urges wives to submit to their husbands and urges husbands to love their wives as their own bodies--for they are no longer two persons but rather "one flesh." 25 By situating his comedy in Ephesus, Shakespeare overlays his stageplay on top of the apostle's instructions, making it so that Paul's matrimonial advice serves as a substratum of sorts. In so doing, Shakespeare calls to mind the difficult demands of marriage and prepares us to appreciate its transformative potential--capable of undoing and remaking the inclinations, orientations, and identities of its participants.

But if the Ephesian setting of the play subtly alludes to an idealized marital relation, patterned after the connection between Christ and his church, the stageplay presents us with something quite different. Instead of a Christ-like marriage, what we get is conjugality in crisis. As the opening scene makes clear, Paul's counsel to the Ephesians is not being heeded by these Ephesians spouses. Adriana is having trouble submitting to her husband, and Antipholus $\mathrm{E}$ is having trouble cherishing his wife. Things only worsen when Antipholus S, mistaken for his twin, spurns Adriana and makes love to her sister, Luciana, and when Antipholus E, barred from his own home, turns away from his wife and seeks out the company of a courtesan. In the ensuing confusions, marriage is pushed to the point of failure as infidelity, adultery, and incest are all put into play. ${ }^{26}$

\footnotetext{
${ }^{24}$ See Titus Maccius Plautus, The Menaechmi, trans. and intro. Palmer Bovie (San Francisco: Chandler Pub. Co., 1962).

${ }^{25}$ See Ephesians 5:22-31, esp. 31.

${ }^{26}$ As Murray advises, twinship was routinely associated with incest and adultery in the early modern imagination. In adapting his source materials, Shakespeare made several changes that increased the odds his twin characters would engage in some type of forbidden sexual activity. However, both Antipholus $S$ and Dromio $S$ turn out to be repulsed by their brothers' wives, rather than attracted to them. Though they are unaware that these women are close relations, they nevertheless seem intuitively to reject the adulterous and incestuous opportunities that Shakespeare takes pains to
} 
In some twin plays, these alternative sexual possibilities are precisely the point. In Plautus's Amphitryon, for instance, the sole reason Jove twins himself with Amphitryon is to sleep with Amphitryon's chaste wife. The gimmick is exciting specifically because it expands the sexual opportunities of men, granting them access to women who would otherwise be unavailable or unwilling. Plautus's play encourages us to applaud Jove's twinning trick as clever and witty; by the time the comedy concludes, even Amphitryon has come to appreciate (and feel honored by!) the manner of his cuckolding. ${ }^{27}$ Shakespeare, however, does not celebrate to the same extent the libertine possibilities that present themselves when wives cannot distinguish between lawful partners and ardent impersonators. Instead of promoting the idea that these types of trysts are relatively harmless, Errors begins to count their costs by giving a voice to the women who would be exploited or injured by them. As is clear from even a cursory comparison, Shakespeare significantly expands upon the female characters found in his source materials. Whereas the merchant's wife in Plautus is an anonymous caricature of a shrew, Shakespeare elects to give her a name, a special eloquence, and an extended speech in which to inveigh against infidelity, laying bare the shame, disappointment, and pain it produces. ${ }^{28}$ By emphasizing what effect these sexual confusions might have on Antipholus E's devoted wife,

proliferate. According to Murray, we can see in this a deliberate attempt on Shakespeare's part to exorcise the idea that twins are constitutionally inclined to that which is unnatural or illicit (see pp. 1523).

${ }^{27}$ See Titus Maccius Plautus, Amphitryon, in Amphytryon and Two Other Plays, ed. and trans. Lionel Casson (New York: W. W. Norton, 1971), pp. 1-64.

${ }^{28}$ In The Menaechmi, the merchant's wife remains anonymous but the courtesan is given a name (Erotium). In Errors, Shakespeare reverses this, bestowing a name on the wife (Adriana) but leaving the courtesan nameless. According to Findlay, Shakespeare's depiction of Adriana makes her "undoubtedly the most sympathetic character of the play" (p. 347). 
the play makes it more difficult to take delight in the erotic misadventures made possible by twinning. When Errors moves in the direction of incest and adultery, then, the stakes are appreciably higher than in the source materials.

In Shakespeare's play, marital ties--at least for Adriana--are not something to be circumvented or swept aside for the sake of novelty or pleasure. She insists throughout the play on the permanence and inviolability of the conjugal connection--perhaps nowhere as powerfully as in the passage partially quoted above in which she avows that she and Antipholus E are "undividable" and "incorporate" and that he can no sooner separate himself from her, his "dear self's better part," than he can extract "unmingled" a single drop of water from the great gulf in which it has been dissolved (see II.ii.120-30). By repurposing in this exchange with her husband the same watery metaphor that Antipholus S has used in his monologue about twinship, Adriana effectively puts the conjugal bond on par with the twinship bond. As she would have it, the conjugal relation is as impactful on Antipholus E's identity as is the aweinspiring material connection between him and his identical twin.

As the play's primary advocate for marriage, Adriana is as creative as she is committed. The conceit of the water droplet is not the only metaphor she adapts and re-deploys to achieve her ends. She repeatedly reinterprets and even inverts conventional tropes of marriage so as to ratchet up the significance of the marital relationship, as well as the rights and responsibilities of its participants. One example of this is her innovative use of the conceit of the elm and the vine, traditionally used to diminish the wife by figuring her as a fragile adornment that must cling to her strong and steadfast husband. In Adriana's hands, however, the metaphor 
empowers more than it demeans--giving Adriana all the justification she needs to lay hands on her husband, fastening on him as forcefully as a vine adheres to the elm.

Come, I will fasten on this sleeve of thine.

Thou art an elm, my husband; I a vine, Whose weakness, married to thy stronger state.

Makes me with thy strength to communicate. (II.ii.173-6)

This interpretive ingenuity also informs Adriana's approach to the biblical idea that husbands and wives are "one flesh." In Shakespeare's day, this idea largely elided the agency of the wife by supposing it to have been engrossed by the ampler agency of the husband, whose agential status in the chauvinistic legal system was assured by his sex. Adriana, however, uses the concept to assert her interest in her husband's affairs. If we two are one, she argues, then your bad acts make me a harlot:

I am possessed with an adulterate blot;

My blood is mingled with the crime of lust.

For if we two be one, and thou play false,

I do digest the poison of thy flesh,

Being strumpeted by thy contagion. (II.ii.140-4)

On the basis of this reasoning, Adriana contests a sexual double standard while also claiming a stake in her husband's being and behavior. Rather than resisting the idea of marriage as a total union, Adriana radicalizes it, using this idea as a means of empowerment.

As brilliant as it may be, Adriana's proto-feminist, pro-marriage position finds little support among the other characters in the play--including the other female characters. Luciana 
openly opposes Adriana in act II, and Emilia stands against her in act V. Because Luciana is not yet married herself, it might be easy to dismiss her opposition to Adriana as ill-informed or naive, but Emilia's attack is particularly powerful inasmuch as the previously married abbess speaks from a place of both experience and authority. Significantly, Adriana does not try to defend herself from Emilia. Yet even if Adriana submits, or at least goes silent, at the end of the play, the case she has made for marriage does not collapse. As the comedy draws to a close, the claims of conjugality continue to butt up against the ties of twinship, with each form of affiliation staking its claims on the identities and affections of the play's principal characters. Because twinship is such an extraordinary arrangement, exciting ideas of mystical or metaphysical connection (e.g., twin telepathy) and because the self-sameness of the identical twins in Errors is so absolute (e.g., sharing the same moles, warts, and birthmarks), we might expect twinship to trump marriage in the end. However, the results are mixed. Twinship appears to take priority in the case of the two Dromios, but marriage seems to win out in the case of the two Antipholuses.

\section{Twinship versus Marriage}

With all its near-misses and false-steps, Errors tantalizes us with the decisive moment when its twins will finally meet face to face and recognize each other. This is the payoff of the twin play, and Plautus, fully aware of this fact, draws it out for as long as he can in The Menaechmi. When his lost twins eventually come together, Plautus prolongs their moment of mutual recognition for more than 100 lines, during which time the crafty slave Messenio painstakingly questions each twin and meticulously connects every dot, until the anagnorisis is 
complete. ${ }^{29}$ In similar fashion, Shakespeare's merchant twins are guided through all the relevant information, item by item, until their situation is made clear to all (see V.i.332-409). In the course of all this elucidation, however, the Dromios are largely overlooked. No one takes the time to talk them through their relationship. What guidance they get comes largely in the form of a single line, spoken by Antipholus $\mathrm{S}$ as he exits the stage. Antipholus $\mathrm{S}$ is on his way to the priory, along with everyone else, when he momentarily pauses and says to his manservant, in the manner of an afterthought, "Embrace thy brother there; rejoice with him" (V.i.415). It is not much--especially when compared with the 80 lines of careful exposition the Antipholuses are given--but it is all the Dromios need. In contrast to their masters, the servant twins take to one another right away. They self-identity in an instant ("I see by you I am a sweet-faced youth" [V.i.420]), and then blithely overleap the substantial matter of seniority:

DRomio E: Will you walk in to see their gossiping?

Dromio S: Not I, sir, you are my elder.

DROMIO E: That's a question. How shall we try it?

Dromio S: We'll draw cuts for the senior. Till then, lead thou first.

Dromio E: Nay, then thus:

We came into the world like brother and brother,

And now let's go hand in hand, not one before another. (V.i.421-7)

It is a rousing bit of bonhomie. In the play's final lines, the Dromios introduce--only to affably dismiss--the question that can turn brotherly pairs into mortal enemies: namely, which one of

\footnotetext{
${ }^{29}$ See Plautus, The Menaechmi, V.viii.
} 
us enjoys the considerable advantages reserved for the eldest son? With effusive good will, the Dromios take each other by the hand, instead of the throat, and enact for us an endearing fantasy of fraternal harmony. ${ }^{30}$

But if the Dromios sweep us up in a dream of brotherly love, they do so in part by sweeping aside the romantic ties that attach to at least one of them. Dromio $\mathrm{S}$ alludes to these ties in the first lines he speaks to Dromio E, referring to his twin's "fat friend" who "shall be my sister." In his reply, Dromio E has nothing to say about his betrothed, attending instead to the sibling who seems to him more like a mirror than a brother.

DROMIO S: There is a fat friend at your master's house, That kitchened me for you today at dinner.

She now shall be my sister, not my wife.

DROMIO E: Methinks you are my glass and not my brother.

I see by you I am a sweet-faced youth.

Will you walk in to see their gossiping? (V.i.416-21)

Although prompted to talk about his future wife, Dromio E switches the subject entirely. By brushing off his romantic obligations, Dromio E indicates that his kinship connection is more consequential than his conjugal one. In this manner, the servants' interaction promotes the

\footnotetext{
${ }^{30}$ Shakespeare stages the opposite scenario in plays such as As You Like It and King Lear, where brothers conspire to kill their counterparts so as to secure or seize the privileges afforded to the firstborn son. For a reading that shows how Errors invokes the possibility of adversarial twinship--in the persons of Jacob and Esau--only to extenuate it, see Patricia Parker "Elder and Younger: The Opening Scene of The Comedy of Errors," SQ 34, 3 (Autumn 1983): 325-7. For a lengthier discussion of the way Errors circumvents the problems of primogeniture that can turn twins into enemies, see my essay "Kinship and Twinship in Jacob and Esau," forthcoming in MRDE.
} 
belief that the connection between husband and wife is nowhere near as intimate or identityaffirming as the ready-made relationship between identical twins.

If we shift our gaze to the other set of twins, however, things look a bit different. Although Antipholus S, when the play opens, is desperate to find his fellow forth, the intensity of his search abates upon encountering and falling for Luciana. Thoughts of his new mistress crowd out thoughts of his missing brother; by the time the twins meet up, Luciana's hold on Antipholus $\mathrm{S}$ is such that he hardly reacts to the sight of his sibling. Antipholus $\mathrm{E}$, for his part, does not show much emotion either--and he does not have the excuse of new love. As John Mercer points out, the reunion of the Antipholus twins is strangely muted. Neither one addresses a single line of dialogue to the other, and there is no indication that they embrace, weep, or show other signs of elation. ${ }^{31}$ Indeed, rather than drawing the twins together, the play puts distance between them: in the final act the Duke commands the merchant twins to "stand apart" to prevent additional mix-ups (V.i.365). Separated from his sibling, each twin is paired instead with his love interest. This blocking would appear to elevate marriage over twinship. By pairing the Antipholus twins with their significant others instead of their sibling, the play invites us to see their marital relations as subsuming them more wholly and completely than their twin relation.

This disposition is a meaningful departure from the source-text. In The Menaechmi, the merchant twins experience such joy at their reunion that they resolve to return together to

\footnotetext{
${ }^{31}$ See John M. Mercer, "Twin Relationships in Shakespeare," UCrow 9 (1989): 24-39, esp. 31.
} 
their homeland. To facilitate his relocation, the Epidamnian twin offers to auction off his estate, and his servant boisterously announces the sale in what are the last lines of the play:

Big auction at Menaechmus' house a week from today!

Must sell slaves, furniture, town house, country estate!

Everything's going, everything, for whatever you can pay!

He'll even sell the wife to any buyer willing to try her. ${ }^{32}$

This sort of sexist slight would likely have elicited a laugh in the Renaissance playhouse, but Shakespeare passes over Plautus's parting shot in favor of an ending that not only affirms the marital ties of the merchant twins but also gives them special status. At the end of Plautus's play, the twin commitment triumphs, while the marital commitment is mocked and (most likely) dissolved. In Errors, on the other hand, all the marriages--save one--are confirmed or reaffirmed at the end, rather than undone. Egeon is restored to Emilia, Antipholus E is returned to Adriana, and Antipholus $S$ is pledged to Luciana. To view the play from this point of view is to see marriage as ascendant over twinship, with each character in the play's merchant class paired up in such a way as to privilege the conjugal over the fraternal/filial.

Yet it must be acknowledged that most of the marital alliances affirmed at the end of the play fall well short of the ideal outlined in Paul's letter to the Ephesians. Antipholus E, for example, continues to have commitment issues. In the final scene, he directs as many lines to the courtesan as he does to Adriana (one line for each), and what he says to the courtesan sounds more affectionate than what he says to his wife. ${ }^{33}$ And without straining too much, we

\footnotetext{
32 Plautus, The Menaechmi, V.viii.

${ }^{33}$ When Adriana asks the wrong twin "And are not you my husband?" Antipholus E brusquely responds, "No, I say nay to that" (V.i.372-3). A little later, when the courtesan asks for the return of her
} 
might wonder what the future holds for Antipholus S and Luciana, given that one of their earliest interactions was an extended lesson from Luciana on the value of being "secret-false."

Broken vows do not seem to bother her, so long as the philandering spouse is clever enough to keep up appearances, "teach[ing] sin the carriage of a holy saint" and "bear[ing] a fair presence, though your heart be tainted" (see III.ii.1-28, esp. lines 13-5)..${ }^{34}$ Neither of the merchant twins, it would seem, is in a rock-solid relationship. But what about their parents?

The reunion of Emilia and Egeon is perhaps more inspiring, alluding, as it does, to the miraculous resurrections and joyful restorations of early modern romance. ${ }^{35}$ Alison Findlay certainly sees the renewal of the parents' marriage as a salvific event. In her view, Egeon's first words to his recovered spouse--"If I dream not, thou art Emilia"--is a momentous acknowledgment that "marks a redeeming moment for social interactions." According to her, the greeting (1) repairs, at a formal level, the misrecognitions that have gone before; (2) "precipitates a series of questions and responses by which the separate identities of the Antipholi are established"; and (3) relegitimates, at least superficially, the single bond between

diamond, Antipholus E graciously replies, "There, take it, and much thanks for my good cheer" (V.i.394). Schalkwyk also contrasts the tone of these two remarks but makes the mistake, I believe, of imagining that Adriana's question "And are you not my husband?" is directed to Antipholus E, so that his "No" amounts to an outright rejection of her (see p. 85). However, I see Adriana's question as aimed at Antipholus $S$, so that Antipholus E's reply is not a repudiation of his marriage but a belligerent reaffirmation of it (along the lines of "Hands off, she's mine!").

${ }^{34}$ Cartwright casts additional doubt on the relationship between Antipholus $\mathrm{S}$ and Luciana by pointing to the pervasive suggestions in the play that his extravagant vision of her is caused by enchantment or mystification (see pp. 339-40).

${ }^{35}$ For a brilliant analysis of how and why Errors oscillates between the divergent modes of romance (as expressed in the Egeon-Emilia plot) and farce (as expressed in the twin plot), see Martine van Elk, "'This sympathizèd one day's error': Genre, Representation, and Subjectivity in The Comedy of Errors," SQ 60, 1 (Spring 2009): 47-72. 
husband and wife and the "chivalric romance" between Luciana and Antipholus S. ${ }^{36}$ In performance, a production could linger on Egeon's words and the cast of actors could add accompanying gestures, actions, and affective displays so as to make these lines do the kind of work Findlay sees them doing. Nevertheless, it bears noting that Egeon's acknowledgment is rather brief. When Emilia reveals herself to Egeon, she implores him to speak to her (three times in the course of five lines), apparently yearning for a poignant reunion. Egeon, however, does not appear to give Emilia the kind words she craves. Instead of addressing his wife at length, Egeon has no sooner identified Emilia than he is inquiring after the son who disappeared with her, as if the lost son were of greater concern than the lost wife.

ABBESS: Speak, old Egeon, if thou beest the man

That hadst a wife once called Emilia,

That bore thee at a burden two fair sons.

0 , if thou beest the same Egeon, speak, And speak unto the same Emilia.

EGEON: If I dream not, thou art Emilia.

If thou art she, tell me, where is that son

That floated with thee on the fatal raft? (V.i.342-6, 353-5; my emphasis)

In asking after Antipholus E, Egeon may simply be trying to close the loop and complete the story, but his question perhaps indicates that he is more interested in recovering his son than

\footnotetext{
${ }^{36}$ Findlay, p. 351.
} 
his wife. Along these lines, we might also note that the play provides little explanation for Egeon's inaction after losing Emilia at sea. Whereas Antipholus S cannot be kept from questing after his missing brother as soon as he comes of age, Egeon exhibits none of the same urgency to find his missing wife. Egeon only happens upon Emilia by chance; the person he was actually seeking was not his spouse but his son. According to Barbara Freedman, this extreme passivity is a form of "marital neglect" that suggests that Egeon's attachment to his wife is attenuated by "his own guilty wish for independence." 37 Even in the case of Egeon and Emilia, then, the play raises red flags about the marital relation. With all three of its merchant-class couples, the play provides hints that "cleaving" could be a challenge.

In sum, none of the marriages in Errors is perfect. To the contrary, they are messy, unstable alliances between two people with divergent biographies, beliefs, expectations, and motivations. On the face of it, it is inconceivable that such a difficult relationship could compare with the special bond between two siblings so self-similar they cannot be told apart. Yet Errors repeatedly juxtaposes its flawed marriages with its marvelous twinships, inviting us to evaluate each of these relationships in terms of the other. And at least in the case of the merchant characters, the play seems to elevate the relationship between husbands and wives over the relationship between identical twins. Significantly, when Antipholus S refers to another character as "mine own self's better part" (III.ii.61), he is not talking about Antipholus E (to whom he never speaks) but Luciana (to whom he pledges himself). At play's end, she is the one with whom he is supposed to be incorporate and indivisible, not his twin.

\footnotetext{
${ }^{37}$ Freedman, p. 240.
} 


\section{Conclusion}

Over the course of this essay, I have proposed that Shakespeare's atypical approach to twins is an outgrowth of his abiding interest in the social components of selfhood. It is my belief that Shakespeare turns to twins because they signify interrelatedness at every level and because their unique connection invites us to weigh the relative importance of individuality and interrelation in the formation of identity. In The Comedy of Errors, I submit, Shakespeare uses his twins to impress upon us the ways in which subjectivity might be an ethical effect, predicated less upon a unique set of personal characteristics and more upon a unique set of personal obligations and responsibilities.

However, I have also proposed that in Errors Shakespeare pits the twin relation against the play's other primary form of interconnection: namely, conjugality. In this juxtaposition, twinship would seem to have the upper hand since twinship, as Shakespeare stages it in Errors, is an impossibly close connection. The twinship pairs in Errors are utterly identical, right down to the smallest mole and wart. This self-sameness enables a host of egoistic fantasies. To be a twin in Errors is to have a perfect partner: an alter ego who looks, talks, thinks, and acts just like one's self. Being a husband or wife, on the other hand, is quite different. As Shakespeare stages it in Errors, marital life is fraught with difficulty. In these relationships, otherness is the rule, not self-sameness. To be a spouse in this play is to struggle to adhere to one who is irreducibly and intransigently unlike the "I."

The mere fact that Errors repeatedly puts its flawed marital connections on par with its fantastical twinship connections speaks volumes. In myriad ways, the comedy insinuates that 
marriage--imperfect, everyday marriage--has as much subjective impact on its characters as the extraordinary bond between identical twins. As intriguing as it might be to see two persons sharing "one face, one voice, one habit," Errors implies that the twin relation does not exceed in importance that even more perplexing union: the "one flesh" that is man and wife. Twinship may be marvelous, but marriage is a marvel in its own right.

Kent Lehnhof is Professor of English at Chapman University. His essays on early modern literature and culture have appeared in a wide range of journals and can be found at www.chapman.academia.edu/KentLehnhof. His current research focuses on philosophical readings of Shakespeare (especially Levinas) and representations of twinship on the Renaissance stage. 